Core ideas

- Fall tillage reduced winter runoff and manure nutrient losses compared to no-tillage

- Nutrient loads were greatest on no-tillage soil with winter-applied liquid manure

- Timing liquid manure application to unfrozen or partially-thawed soil reduced loss

\title{
Fall Tillage Reduced Nutrient Loads from Liquid Manure Application during the Freezing Season
}

\author{
Melanie N. Stock ${ }^{\mathrm{a}^{*}}$, Francisco J. Arriaga ${ }^{\mathrm{b}}$, Peter A. Vadas ${ }^{\mathrm{c}}$, Laura W. Good ${ }^{\mathrm{d}}$, Michael D. Casler,
} K.G. Karthikeyan ${ }^{\mathrm{f}}$, and Zachariah Zopp ${ }^{\mathrm{g}}$

aUtah State University, Department of Plants, Soils, \& Climate, 4820 Old Main Hill Logan, UT 84321, USA;

melanie.stock@usu.edu

bUniversity of Wisconsin-Madison, Department of Soil Science, 1525 Observatory Drive Madison, WI 53706, USA; farriaga@wisc.edu

'USDA-ARS, U.S. Dairy Forage Research Center, 1925 Linden Dr., Madison, WI 53706, USA;

peter.vadas@ars.usda.gov

'University of Wisconsin-Madison, Department of Soil Science, 1525 Observatory Drive Madison, WI 53706, USA; lwgood@wisc.edu

eUSDA-ARS, U.S. Dairy Forage Research Center, 1925 Linden Dr., Madison, WI 53706, USA;

michael.casler@ars.usda.gov

fUniversity of Wisconsin-Madison, Department of Biological Systems Engineering, 460 Henry Mall, Madison, WI 53706, USA; kkarthikeyan@wisc.edu

EUniversity of Wisconsin-Madison, Department of Biological Systems Engineering, 460 Henry Mall, Madison, WI 53706, USA; zopp@wisc.edu

*Corresponding author

Abbreviations: $\mathrm{C}$, unmanured control treatment; CT, fall tillage with a chisel plow and spring finisher; $\mathrm{CT}-\mathrm{C}$, fall tillage and unmanured control treatment; $\mathrm{CT}-\mathrm{D}$, fall tillage treatment with December manure application timing; $\mathrm{CT}-\mathrm{J}$, fall tillage treatment with January manure application timing; D, December manure application timing treatment; DM, dry matter; DRP, dissolved reactive phosphorus; J, January manure application timing; NH4-N, ammonium-N; NO3-N, nitrate-N; NT, no-tillage; NT - C, no-tillage and unmanured control treatment; NT - D, notillage treatment with December manure application timing; NT - J, no-tillage with January manure application timing treatment; SWE, snow-water equivalent; TKN, total Kjeldahl nitrogen; TN, total nitrogen; TP, total phosphorus; TS, total solids; VS, volatile solids.

\begin{abstract}
Reducing agricultural runoff is important year-round, particularly on landscapes that receive wintertime applications of manure. No-tillage systems are typically associated with reduced runoff loads during the growing season, but surface roughness from fall tillage may aid infiltration on frozen soils by providing surface depressional storage. The timing of winter manure applications may also affect runoff depending on snow and soil frost conditions. Therefore, the objective of this study was to evaluate runoff and nutrient loads during the freezing season from combinations of
\end{abstract}


tillage and manure application timings. Six management treatments were tested in south-central Wisconsin during the winters of 2015-16 and 2016-17 with a complete factorial design: two tillage treatments (fall chisel plow versus no-tillage) and three manure application timings (early December, late January, and unmanured). Nutrient loads from winter manure application were lower on chisel-plowed versus untilled soils during both monitoring years. Loads were also lower from manure applied to soils with less frost development. Wintertime manure applications pose a risk of surface nutrient losses, but fall tillage and timing applications to thawed soils can help reduce loads.

\section{INTRODUCTION}

Balancing production with environmental sustainability is a critical challenge for manure management in animal production systems. Land-application of manure is a longstanding practice for recycling farm nutrients back to cropland, but research has demonstrated that surface manure application to fields without incorporation can be a significant source of nitrogen $(\mathrm{N})$ and phosphorus (P) losses in surface runoff (Daniel et al., 1998; Kleinman and Sharpley, 2003; Vadas et al., 2007). For many northern U.S. states, as well as Canadian provinces and northern European countries, manure is applied year-round, and must be left unincorporated during winter because of the presence of frozen soils and snow. Winter application can help reduce manure storage expenses, provide more time for field operations in other seasons, and avoid soil compaction, but it can lead to elevated runoff risks from frozen soils, snowmelt, and rain-on-snow events (Srinivasan et al., 2006; Liu et al., 2017).

Over half of annual runoff can occur during the winter season in temperate regions with snow and frozen soils present (Good et al., 2012; Stuntebeck et al., 2011), and consequently there are regulations and recommendations restricting winter manure spreading to protect water quality (Srinivasan et al., 2006; Liu et al., 2018). Limited data exist, however, that quantify manure nutrient loads in runoff following winter application. Most research has been observational with little replication, has taken place prior to 1980 , and has focused on solid manure (13.8-55.5\% dry matter, DM), which was most common at that time (Hensler et al., 1970; Converse et al., 1976; Klausner et al., 1976; Phillips et al., 1981; Steenhuis et al., 1981; Young and Mutchler, 1976; 
Young and Holt, 1977). Generally, nutrient loads in runoff were greater from manure applied early in the winter to frozen ground without snowpack, compared to late-winter applications on top of frozen ground with snowpack (Hensler et al., 1970; Converse et al., 1976; Young and Mutchler, 1976). The mulching effect of solid-bedded manure explained this trend. When applied onto snow, solid manure reduced runoff by retarding melt and providing more time for snowmelt and manure nutrients to infiltrate into soil (Kongoli and Bland, 2002).

The plot-scale research of the 1970s focused on solid manure and may not directly relate to runoff from more liquid forms $(<11 \% \mathrm{DM})$. Since the 1990s, the number of larger dairy farms increased by $70 \%$, smaller farms ( $<500$ head) decreased by $49 \%$, and $90 \%$ of farms with greater than 200 head now produce liquid manure (USDA-NASS, 2010). This manure is expected to interact differently with snowpack than solid manure. For example, liquid manure applied onto snow infiltrates and remains in the snowpack instead of maintaining a thick, insulative layer (Kongoli and Bland, 2002; Vadas et al., 2017; Vadas et al., 2018) and may be prone to runoff because of its high water content. In a comparison of winter-applied liquid swine manure (4\% $\mathrm{DM})$ to turkey litter $(57 \% \mathrm{DM})$, nutrient runoff loads were greater from the liquid manure, despite greater nutrient amounts applied with the litter (Owens et al., 2011). Liquid manure applications may pose greater risk to nutrient loss because the infiltrated manure liquid has greater physical contact with snowmelt water for nutrient release, as opposed to solid manure that remains on the snow in a discrete layer (Vadas et al., 2017). Other field research investigated liquid dairy manure applications at the basin scale (7-16 ha) and found the greatest nutrient loads from liquid manure occurred when applied within one week of a runoff event (Komiskey et al., 2011). However, runoff loads could not be attributed to specific practices because of multiple manure timings, application rates, manure types, and lack of replication. Research is still needed to understand the impact of 
specific management practices and runoff hydrology processes to reliably quantify the risk for nutrient loads from winter manure application.

The effect of tillage on winter runoff and nutrient loads is also unclear, particularly for frozen soils (Komiskey et al., 2011). During the growing season, no-tillage is generally considered to increase infiltration and maintain soil aggregate stability, thereby reducing nutrient transport via erosion and runoff (Zhang et al., 2006). However, as soils freeze and infiltration decreases, the smooth surface of no-tillage may increase runoff (Ranaivoson et al., 2005). Nutrient accumulation near the soil surface from lack of tillage may increase dissolved nutrient loads compared to conventional tillage (Tiessen et al., 2010). Moreover, wintertime nutrient release from vegetation in no-tillage, perennial forage systems can elevate losses (Liu et al., 2014). Young and Mutchler (1976) compared runoff for continuous corn with fall tillage and harrowing versus no-tillage alfalfa, both with winter-applied, solid dairy manure. Despite tilling parallel to the slope, significantly greater runoff occurred from alfalfa, with winter nutrient loads over five times greater on soils with no-tillage. Depending on study year, $9-42 \mathrm{~kg} \mathrm{ha}^{-1}$ more total nitrogen and $3-6 \mathrm{~kg}$ $\mathrm{ha}^{-1}$ more total phosphorus were lost from manure applied to frozen soils with no-tillage versus tillage (nutrient release from alfalfa accounted for up to $0.5 \mathrm{~kg} \mathrm{P} \mathrm{ha}^{-1}$ of losses based on the unmanured controls). Similarly, Hansen et al. (2000) observed that springtime nutrient loads decreased with increasing surface roughness across three tillage systems (ridge-tillage, chisel plow with spring disking, and fall moldboard), despite tillage parallel to the slope.

Ultimately, the impact of management to reduce nutrient runoff from winter-applied liquid manure has been difficult to assess from literature data due to differences in study designs, wideranging weather within and between years, and a lack of data to analyze the hydrologic and manure property controls on nutrient loss (e.g. Klausner et al., 1976; Owens et al., 2011; Komiskey et al., 
2011). Our main goal is to improve the understanding and modeling of biochemical and physical processes controlling frozen-soil and snowmelt infiltration, runoff, and nutrient loads from soil and winter-applied dairy manure through a series of lab and plot-scale experiments (Vadas et al., $2017 ; 2018)$. The objective of this study was to investigate winter surface runoff and nutrient loads for variations in tillage and timing of winter manure application that are common management practices in temperate states. Specifically, we tested tillage with a fall chisel plow versus no-tillage, and manure applications timed 1) early in the freezing season (early-December), 2) later in the freezing season (late-January), and 3) with unmanured controls. Here, we report plot-scale observations on the effect of tillage and winter manure application timing on overall winter runoff amounts and nutrient loads across the freezing season. Vadas et al. (this issue) describes runoff hydrology and nutrient concentrations on an event-by-event basis. We hypothesized that fall tillage will reduce runoff through surface roughness and manure applications later in the freezing season will result in greater losses because of greater frost development and snow accumulation.

\section{MATERIALS AND METHODS}

\section{Site description and treatments}

We conducted the study at the University of Wisconsin Arlington Agricultural Research Station (AARS; $43^{\circ} 17^{\prime} \mathrm{N} 89^{\circ} 21^{\prime} \mathrm{W}$ ) using 18 plots ( 5 x $15 \mathrm{~m}$ each) established on a $5.8 \%$ slope with south-facing aspect and a silt-loam texture (Saybrook-Ringwood-Griswald series association). For four years prior to the study (2011-14), the field was under no-tillage alfalfa. During the study (2015-17), the field was in continuous corn for silage with a 76-cm row spacing. All field operations were performed along the contour.

We evaluated two tillage and three manure timing treatments in a complete factorial design during two winters (2015-16 and 2016-17). Tillage treatments were tillage with a fall chisel and 
spring soil finisher (CT) and no-tillage (NT), to result in rough and smooth surfaces, respectively, during the winter. The soils were tilled on 02 October 2015 and 05 October 2016. In fall 2015, Bray-1 soil test $\mathrm{P}$ was 32 and $51 \mathrm{mg} \mathrm{kg}^{-1}$ for $\mathrm{CT}$ and NT, respectively, at a $0-2.5 \mathrm{~cm}$ depth. In fall 2016, Bray-1 soil test $\mathrm{P}$ was 31 and $39 \mathrm{mg} \mathrm{kg}^{-1}$ for CT and NT at a $0-2.5 \mathrm{~cm}$ depth. Timing of manure applications included early-December at the typical onset of the soil freezing (D), lateJanuary (J), and an unmanured control (C). The manure application dates were 10 December 2015, 26 January 2016, 09 December 2016, and 27 January 2017. All treatment combinations were replicated in triplicate. The experimental design was a paired-plot design in which there were 10 pairs (Supplemental Figure 1). Five of the pairs were assigned to NT and five pairs were assigned to $\mathrm{CT}$, arranged in a completely randomized design. Two of the three manure treatments were assigned within each pair, completely at random, but balanced between NT and CT treatments. There were two "empty" plots, assigned at random within the field area.

We manually applied liquid dairy manure at a rate of $37.4 \mathrm{~kL} \mathrm{ha}^{-1}$. Six to 12 samples collected during each application were analyzed by the University of Wisconsin Soil and Forage Analysis Laboratory (Marshfield, WI, USA) (Table 1). Total N was measured by using methods of Peters et. al. (2003), Section 3.2. After dry ashing, P and potassium concentrations were measured with colorimetric spectrophotometry (Section 5.2). Total solids (TS) and volatile solids (VS) were measured as percentages according to Standards Methods 2540 B and 2540 E (APHA, 1996).

Table 1. The dates and nutrient additions for each manure application with the corresponding field conditions during the application dates.

\begin{tabular}{|c|c|c|c|c|c|c|c|}
\hline \multirow[b]{2}{*}{$\begin{array}{l}\text { Application } \\
\text { Date }\end{array}$} & \multicolumn{5}{|c|}{ Manure Analysis ${ }^{\dagger}$} & \multicolumn{2}{|c|}{ Field Conditions ${ }^{\dagger}$} \\
\hline & TN & $\begin{array}{c}\text { TP } \\
\mathrm{kg} \mathrm{ha}\end{array}$ & TK & TS & $\begin{array}{l}\mathbf{V S} \\
]--\end{array}$ & $\begin{array}{c}\text { Frost Depth } \\
{[\mathrm{cm}]}\end{array}$ & $\begin{array}{l}\text { SWE } \\
{[\mathrm{mm}]}\end{array}$ \\
\hline 10 Dec. 2015 & 65.9 & 8.7 & 68.2 & 2.0 & 1.3 & 0.0 & 0 \\
\hline 26 Jan. 2016 & 80.6 & 11.3 & 56.3 & 2.9 & 2.0 & $0.0-50.1$ & 24 \\
\hline 09 Dec. 2016 & 102.9 & 17.8 & 53.1 & 5.8 & 4.4 & $0.0-10.4$ & 10 \\
\hline 27 Jan. 2017 & 99.2 & 14.4 & 57.5 & 5.5 & 4.1 & $6.2-43.9$ & 31 \\
\hline
\end{tabular}

$\mathrm{TTN}=$ total nitrogen, $\mathrm{TP}=$ total phosphorus, $\mathrm{TK}=$ total potassium, $\mathrm{TS}=$ total solids, and $\mathrm{VS}=$ volatile solids from manure on each of the four application dates. SWE = snow-water equivalent. 


\section{Field measurements}

An on-site weather station was used to measure air temperature (VP-3, Decagon Devices Inc., Pullman WA) and precipitation as rainfall (RG3, Onset Computer Corporation, Bourne, MA) or liquid equivalent of snowfall (adaptor: CS705, Campbell Scientific, Inc., Logan, UT). Soil frost depth was manually measured with one frost tube per plot (Rickard and Brown, 1972; MacKay, 1973), and snow depth with three snow sticks installed equidistantly along the slope of each plot. Snow-water equivalent (SWE, depth of water stored as snow in $\mathrm{mm}$ ) was calculated by measuring snow density with a snow corer in each plot (U.S. Army Corps of Engineers, 2015). Manual measurements of frost and snow were collected at least once per week, and up to daily during precipitation and thaw events.

Runoff volumes were monitored from each plot with a storm-integrated, discharge-weighted collection system (Bonilla et al., 2006; Vadas and Powell, 2013). Earthen berms hydrologically isolated each plot. Runoff was directed into a passive, divider collection system that consisted of three, sequential 19 L buckets for each plot. The first two buckets each had a steel crown with 24 precision-cut, V-slot weirs that directed $1 / 24$ th of the runoff water to the subsequent bucket, allowing for up to a $152 \mathrm{~mm}(11.4 \mathrm{~kL})$ runoff event to be measured. After each runoff event, we measured the height of the water in the buckets with a meter stick to the nearest $\mathrm{mm}$. To determine nutrient loads for each plot, we collected a water sample from each bucket as the water was agitated. The total runoff volume and nutrient loads for each plot were then calculated from the dilution ratio of the weirs. "Runoff ratios" (the proportion of runoff to the total water that interacted with manure through rain and snowmelt) were also calculated and are described in more detail by Vadas et al. (this issue). 
Runoff samples were stored at $4^{\circ} \mathrm{C}$. Unfiltered samples were analyzed for TS and VS (APHA, 1995). Acid preserved ( $\left.2 \mathrm{~mL} \mathrm{~L}^{-1} \mathrm{H}_{2} \mathrm{SO}_{4}\right)$ samples were analyzed for Total Kjeldahl $\mathrm{N}$ (TKN; USEPA, 1993) and Total Kjeldahl P (TKP; SEAL Analytical Inc., 2015) with an automated colorimetric analyzer after digestion (AQ2 Discrete Analyzer, SEAL Analytical Brand, Mequon, WI). Filtered samples $(0.45 \mu \mathrm{m})$ were analyzed for dissolved reactive P (DRP; Murphy and Riley, 1962), ammonium- $\mathrm{N}\left(\mathrm{NH}_{4}-\mathrm{N}\right)$ with QuickChem Methods 12-107-06-2-A $\left(\mathrm{NH}_{4}-\mathrm{N}\right)$, and nitrate- $\mathrm{N}$ $\left(\mathrm{NO}_{3}-\mathrm{N}\right)$ with QuickChem Methods 12-107-04-1-B $\left(\mathrm{NO}_{3}-\mathrm{N}\right)$ on a Lachat automated analyzer. Total $\mathrm{N}(\mathrm{TN})$ was calculated as the sum of TKN and $\mathrm{NO}_{3}-\mathrm{N}$. Nutrient loads were calculated by multiplying the nutrient concentrations by the runoff volume for each plot.

\section{Statistical Analysis}

We tested total runoff volume and cumulative nutrient loads $\left(\mathrm{kg} \mathrm{h}^{-1}\right)$ across three monitoring periods each year by summing all events for each plot for each period. Periods included "prefreezing", "frozen-ground", and "post-freezing", which accounted for changes in hydrology from soil frost dynamics. Pre-freezing was from the start of monitoring on 24 Nov. until the soil froze (we considered the soil to be frozen when $0.5 \mathrm{~cm}$ of soil frost persisted for at least 24 hours). "Frozen-ground" was when frost was present in all or part of the soil profile, and "post-freezing" was when the soil profile fully thawed until the end of monitoring on 30 Apr. each year.

Corresponding dates for all periods are in Table 2. Frozen-ground and post-freezing periods of 2016-17 were discontinuous because the soil thawed between 23 Feb. and 02 Mar. 2017, and refroze on 03 Mar. 2017. The number of runoff events for all periods is in Table 2. 
Table 2. Pre-freezing, frozen-ground, and post-freezing periods during the 2015-16 and 2016-17 monitoring seasons according to soil frost dates. Precipitation for each period is given as rainfall and snowfall, with snowfall expressed in liquid equivalents (SWE). Corresponding runoff events are given for soils with no-tillage (NT) and fall tillage with a chisel plow (CT).

\begin{tabular}{|c|c|c|c|c|c|c|c|}
\hline \multirow[t]{2}{*}{ Year } & \multirow[t]{2}{*}{ Period } & & \multirow[t]{2}{*}{$\begin{array}{l}\text { \# Days } \\
\text { Frozen }\end{array}$} & \multicolumn{2}{|c|}{$\begin{array}{c}\text { Precipitation } \\
--[\mathrm{mm}]--\end{array}$} & \multicolumn{2}{|c|}{$\begin{array}{c}\text { \# Runoff } \\
\text { Events }\end{array}$} \\
\hline & & & & Rain & SWE & NT & CT \\
\hline \multirow{3}{*}{$\begin{array}{l}2015- \\
2016\end{array}$} & Pre-freezing & 24 Nov -29 Dec & \multirow{3}{*}{74} & 132 & 7 & 2 & 0 \\
\hline & Frozen-ground & $30 \mathrm{Dec}-11 \mathrm{Mar}$ & & 24 & 24 & 5 & 1 \\
\hline & Post-freezing & $12 \mathrm{Mar}-30 \mathrm{Apr}$ & & 105 & 17 & 2 & 0 \\
\hline \multirow{3}{*}{$\begin{array}{l}2016- \\
2017\end{array}$} & Pre-freezing & 24 Nov -06 Dec & \multirow[t]{3}{*}{$94 \dagger$} & 75 & 12 & 1 & 0 \\
\hline & Frozen-ground & 07 Dec - 22 Feb, $03-20$ Mar & & 102 & 87 & 8 & 6 \\
\hline & Post-freezing & $23 \mathrm{Feb}-02 \mathrm{Mar}, 21 \mathrm{Mar}-30 \mathrm{Apr}$ & & 163 & 7 & 1 & 0 \\
\hline
\end{tabular}

$\dagger$ The frozen-ground and post-freezing periods of 2016-17 are discontinuous because the soil thawed between 23 Feb. and 02 Mar. 2017, and refroze by 03 Mar. 2017.

We analyzed data with the GLIMMIX procedure of SAS® software (version 9.4, Copyright $($ ) 2013, SAS Institute Inc., Cary, NC, USA). Slope position, pair, and pair x tillage were treated as random effects and Akaike Information Criterion (AIC) was used to determine which random effects belonged in the model. Tillage, manure treatments, and their interactions were the only fixed effects. Data were modeled using the lognormal distribution, which resulted in residual plots that generally demonstrated randomly distributed errors and homogenous variances. Fixed effects of tillage, manure timing, and their interaction were assessed by differences of least squares means with the Bonferroni adjustment for multiple comparisons $(\alpha=0.05)$. The interaction of manure timing with tillage was evaluated by computing and testing simple effects of manure timings within each of the tillage treatments. All significance tests were conducted on lognormal data with the $\log$ transformation and least squares means were all back-transformed prior to presentation in tables and figures. Standard errors of back-transformed means were computed according to the Taylor expansion (Stroup, 2013). 


\section{RESULTS AND DISCUSSION}

\section{Hydrology}

Weather and soil freezing conditions are drivers of runoff hydrology during the winter, and conditions of the two monitoring seasons caused significant differences in runoff hydrology. In 2015-16, the soil froze on 30 December, 41 days later than the 10-year average (University of Wisconsin, 2010), which resulted in the December manure application occurring during the prefreezing period and the January application during the frozen-ground period. Most precipitation fell as rain (Figure 1a, Table 2) during the pre- and post-freezing periods (12 weeks, $84 \%$ of precipitation) compared to the frozen-ground period (11 weeks, 16\%). In December 2015, total precipitation was over two times greater than normal, while air temperature was seven degrees greater and above freezing (1981-2010; NOAA, 2017). Weather during January 2016 was near normal, but February 2016 had about one-third less precipitation and greater air temperature than normal (please see the supplemental table for more comparisons with normals). These conditions generated more frequent runoff events and statistically greater runoff volumes from NT soils (9 events, $39 \mathrm{~mm}$ ) than CT (1 event, $1 \mathrm{~mm}$ ) (Tables 2 and 3, Figure 2). Runoff events from NT soils were fairly evenly distributed across unfrozen and frozen-ground periods (four and five events, respectively), and the single event from CT soils was during the frozen-ground period. The cumulative runoff volume from NT was ten times greater than $\mathrm{CT}$, which was statistically significant (Table 3). Moreover, the seasonal average of runoff ratios calculated for each event (Nov. 2015 - Mar. 2016) were eight times greater across NT than CT, indicating NT was consistently more prone to runoff across rain and snowmelt events. The depressional storage created by the fall chisel plow operation caused these runoff differences, which corroborates the findings of Young and Mutchler (1976) and Hansen et al. (2000) on tillage. Soils with CT had a 
network of ridges and furrows oriented along the contour, which provided areas for rainfall and snowmelt to pond, allowing more time for infiltration. From field observation, the smooth surface of NT soils was unable to retard runoff.
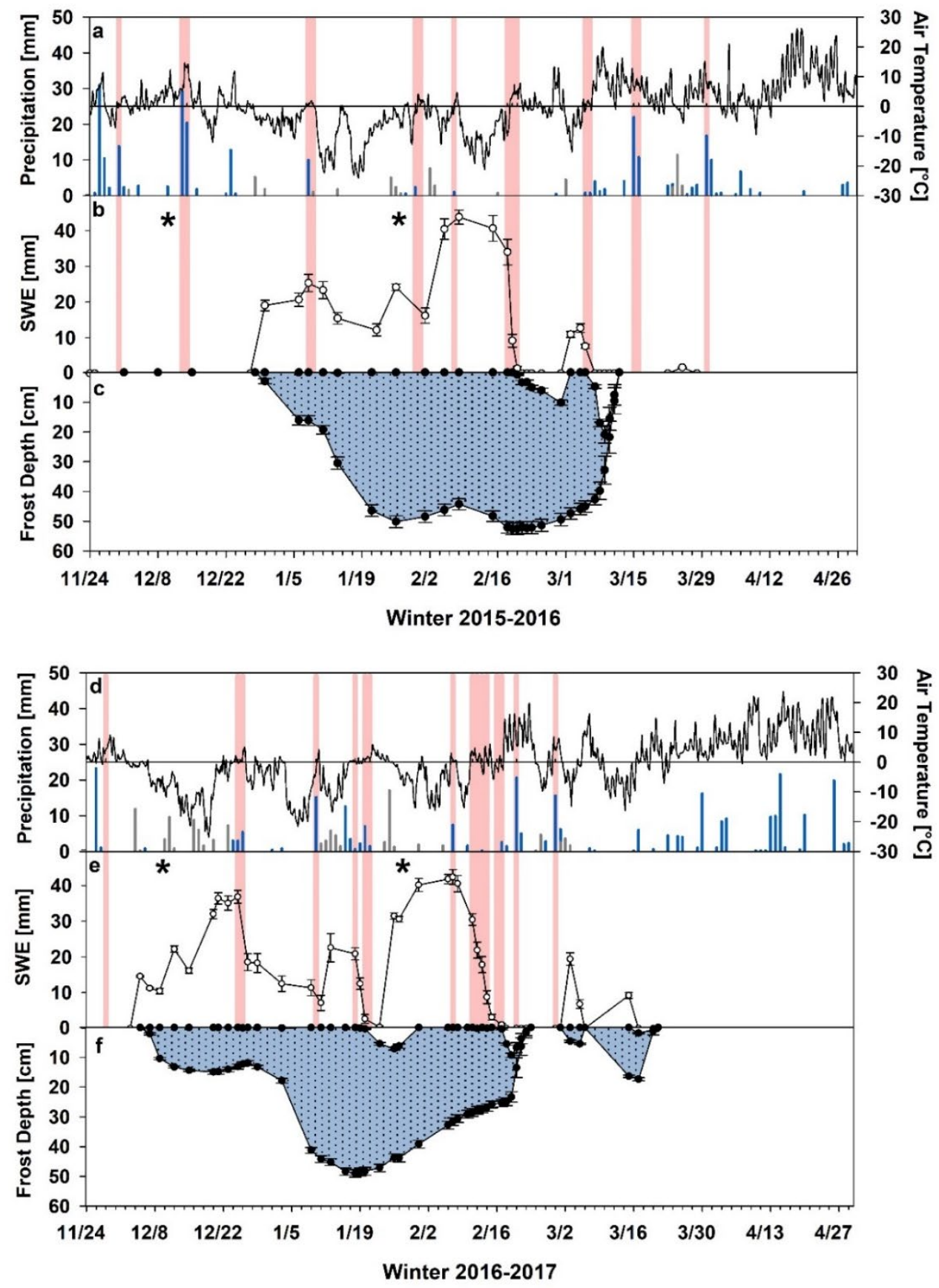

Figure 1. Average hourly air temperature and total daily precipitation as rainfall or the liquid equivalent of snowfall during a) 2015-16 and d) 2016-17; the snow-water equivalent (SWE) of snowpack during b) 2015-16 and e) 2016- 
17; and the average frost depth during c) 2015-16 and f) 2016-17. Runoff event dates are designated in a, b, d, and $\mathrm{e}$; and manure application dates are denoted with an asterisks in $\mathrm{b}$ and $\mathrm{e}$.

Table 3. Treatment means and $p$-values for comparisons of tillage, manure timing, and tillage $\mathrm{x}$ manure timing effects on total loads in the 2015-16 monitoring season $\dagger$.

\begin{tabular}{|c|c|c|c|c|c|c|c|c|c|}
\hline \multirow{2}{*}{\multicolumn{3}{|c|}{ Effect }} & \multirow{2}{*}{\begin{tabular}{|l}
$\begin{array}{l}\text { Runoff } \\
{[\mathrm{mm}]}\end{array}$ \\
\end{tabular}} & \multirow[t]{2}{*}{ TKP } & \multirow[t]{2}{*}{ DRP } & \multirow{2}{*}{$\begin{array}{c}\text { TN } \\
\left.h a^{-1}\right]\end{array}$} & \multirow{2}{*}{$\mathrm{NH}_{4}^{+}$} & \multirow{2}{*}{\multicolumn{2}{|c|}{$\begin{array}{lc}\text { TS } & \text { VS } \\
-- & {\left[\mathrm{kg} \mathrm{ha}^{-1}\right]--}\end{array}$}} \\
\hline & & & & & & & & & \\
\hline \multirow{3}{*}{ 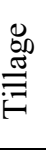 } & Tillage with chisel (CT) & & 1.3 & 7.2 & 3.8 & 56.7 & 11.9 & 2.7 & 1.1 \\
\hline & No-Tillage (NT) & & 38.8 & 1432 & 209 & 5943 & 525 & 746 & 126 \\
\hline & CT vs. NT & $p=$ & 0.01 & $<0.01$ & $<0.01$ & 0.01 & 0.01 & $<0.01$ & 0.01 \\
\hline \multirow{6}{*}{ 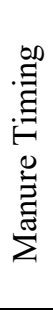 } & Control (C) & & 5.5 & 55.2 & 8.8 & 336 & 38.3 & 33.8 & 9.0 \\
\hline & December (D) & & 4.2 & 42.5 & 9.3 & 291 & 27.2 & 26.2 & 6.5 \\
\hline & January $(\mathrm{J})$ & & 15.7 & 443 & 269 & 2005 & 476 & 99.8 & 29.5 \\
\hline & C vs. D & $p=$ & 1.00 & 1.00 & 1.00 & 1.00 & 1.00 & 1.00 & 1.00 \\
\hline & C vs. J & $p=$ & 0.11 & 0.01 & $<0.01$ & 0.02 & 0.01 & 0.11 & 0.12 \\
\hline & D vs. J & $p=$ & 0.03 & $<0.01$ & $<0.01$ & 0.01 & $<0.01$ & 0.03 & 0.03 \\
\hline \multirow{12}{*}{ 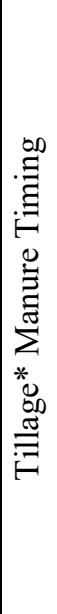 } & $\mathrm{CT}-\mathrm{C}$ & & 0.9 & 3.5 & 1.1 & 33 & 5.3 & 1.6 & 0.9 \\
\hline & $\mathrm{CT}-\mathrm{D}$ & & 0.4 & 1.5 & 0.8 & 17 & 3.1 & 0.9 & 0.4 \\
\hline & $\mathrm{CT}-\mathrm{J}$ & & 5.7 & 70 & 61 & 326 & 104 & 13 & 5.0 \\
\hline & $\mathrm{NT}-\mathrm{C}$ & & 33.0 & 881 & 68 & 3379 & 275 & 720 & 94 \\
\hline & NT $-\mathrm{D}$ & & 40.6 & 1197 & 113 & 5045 & 241 & 769 & 122 \\
\hline & NT $-J$ & & 43.5 & 2784 & 1192 & 12313 & 2191 & 750 & 174 \\
\hline & $\mathrm{CT}-\mathrm{C}$ vs. $\mathrm{CT}-\mathrm{D}$ & $p=$ & 0.60 & 0.34 & 1.00 & 0.66 & 1.00 & 0.93 & 0.56 \\
\hline & $\mathrm{CT}-\mathrm{C}$ vs. $\mathrm{CT}-\mathrm{J}$ & $p=$ & 0.06 & 0.01 & $<0.01$ & 0.03 & 0.01 & 0.04 & 0.10 \\
\hline & $\mathrm{CT}-\mathrm{D}$ vs. $\mathrm{CT}-\mathrm{J}$ & $p=$ & 0.05 & 0.01 & 0.02 & 0.03 & 0.05 & 0.01 & 0.03 \\
\hline & $\mathrm{NT}-\mathrm{C}$ vs. NT $-\mathrm{D}$ & $p=$ & 1.00 & 1.00 & 0.94 & 1.00 & 1.00 & 1.00 & 1.00 \\
\hline & $\mathrm{NT}-\mathrm{C}$ vs. NT $-\mathrm{J}$ & $p=$ & 1.00 & 0.15 & 0.01 & 0.16 & 0.05 & 1.00 & 1.00 \\
\hline & NT $-\mathrm{D}$ vs. NT $-\mathrm{J}$ & $p=$ & 1.00 & 0.21 & 0.01 & 0.26 & 0.02 & 1.00 & 1.00 \\
\hline
\end{tabular}

†TKP $=$ total Kjeldahl phosphorus, $\mathrm{DRP}=$ dissolved reactive phosphorus, $\mathrm{TN}=$ total nitrogen, $\mathrm{NH}_{4}{ }^{+}=$ammonium, $\mathrm{TS}=$ total solids, $\mathrm{VS}=$ volatile solids. Tillage*Manure Timing treatments are: $\mathrm{CT}-\mathrm{C}=$ chisel control, $\mathrm{CT}-\mathrm{D}$ $=$ chisel with December manure, $\mathrm{CT}-\mathrm{J}=$ chisel with January manure, NT $-\mathrm{C}=$ no-tillage control, NT $-\mathrm{D}=$ notillage with December manure, NT $-\mathrm{J}=$ no-tillage with January manure. 

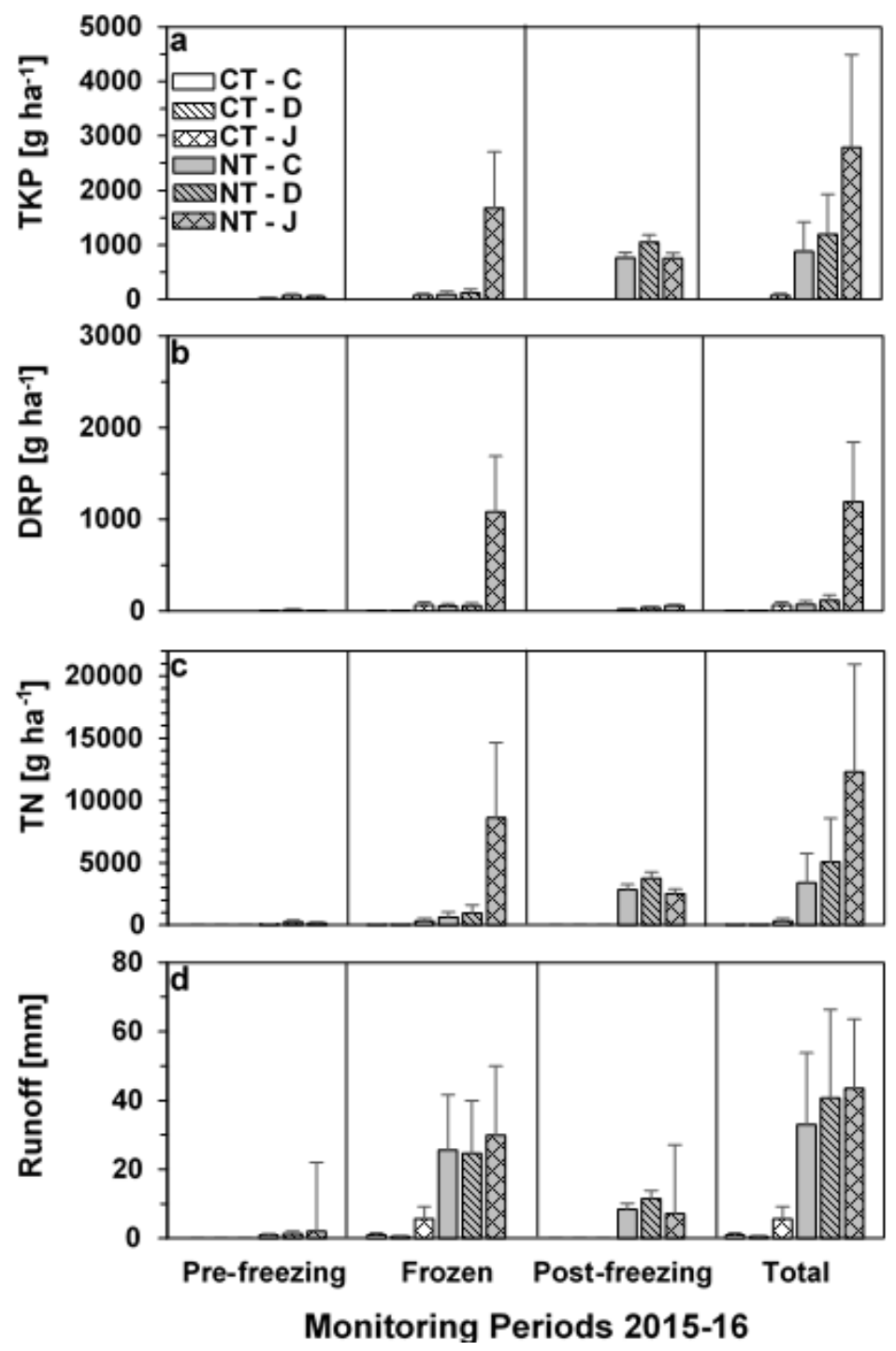

Figure 2. Treatment means ( \pm standard error) of a) Total Kjeldahl phosphorus (TKP), b) dissolved reactive phosphorus (DRP), c) total nitrogen (TN), and d) runoff by tillage x manure timing treatments during the 2015-16 monitoring season. Nutrients and runoff are shown within the pre-freezing, frozen-ground, and post-freezing periods, as well as the cumulative of the three periods (Total). [CT = fall tillage with a chisel plow, NT = no-tillage, Control $=$ no manure, Dec $=$ December manure timing, Jan $=$ January manure timing $]$.

In 2016-17, runoff was also more frequent and of greater magnitude from NT soils (10 events, $44 \mathrm{~mm}$ ) than CT soils (6 events, $31 \mathrm{~mm}$ ), but not as much as in 2015-16 (Tables 2 and 4, Figure 3). In fact, the $30 \%$ more runoff from NT soils was not statistically significant for tillage as a main effect (Table 4) and the runoff ratios of NT were only two times greater than CT in this second year. The greater runoff from $\mathrm{CT}$ in the second winter compared to the first winter is likely a function of contrasting soil freezing and weather conditions. Compared to 2015-16, soil froze 23 
days earlier in 2016-17 (but still 18 days later than the 10-year average (University of Wisconsin, 2010)), there was $44 \%$ more precipitation across the entire winter, and the frozen-ground period had nearly four times as much rain and snow (Figure $1 \mathrm{~d}-\mathrm{f}$, Table 2). Therefore, the pre-and postfreezing periods ( 8.5 weeks) were shorter, the frozen-ground period (13.5 weeks) was longer and included both the December and January manure applications, and precipitation was more evenly distributed across the frozen-ground and non-frozen periods ( $42 \%$ and $58 \%$, respectively) (Figure 1, Table 2), which increased runoff ratios across tillages. Dec. 2016 - Feb. 2017 had two to three times greater monthly precipitation than normal, while air temperature was most notably greater than normal in February (NOAA, 2017). These conditions caused greater runoff on CT soils in this second winter season, as all six events were during the frozen ground period (Table 2). The weather conditions of 2016-17, particularly greater amounts of rain and more frequent melt events, increased runoff by both compromising and overflowing some ridges that structured the surface depressional storage on CT soil. 
Table 4. Treatment means and p-values for comparisons of tillage, manure timing, and tillage*manure timing effects on total loads in the 2016-17 monitoring season†.

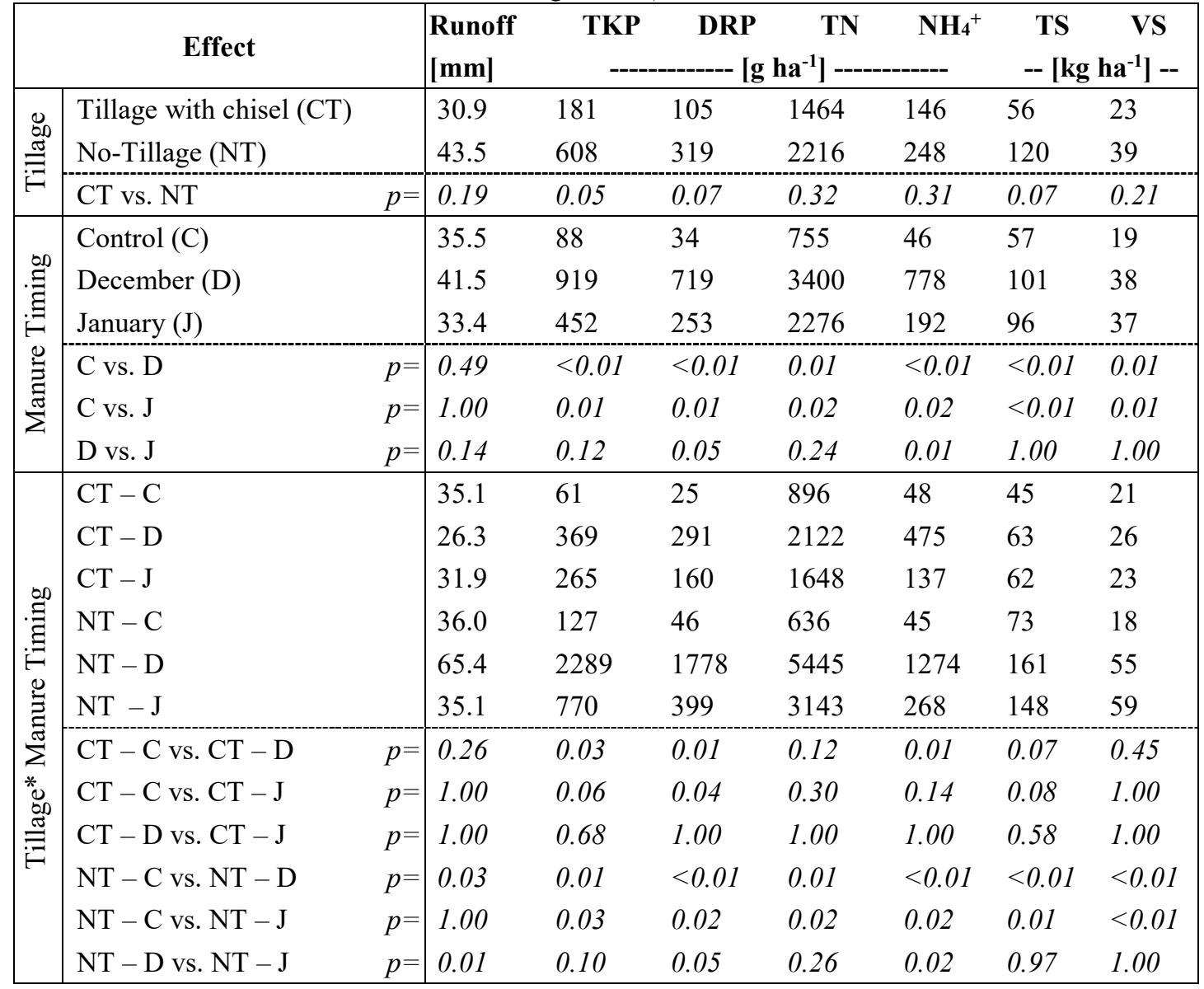

†TKP $=$ total Kjeldahl phosphorus, $\mathrm{DRP}=$ dissolved reactive phosphorus, $\mathrm{TN}=$ total nitrogen, $\mathrm{NH}_{4}{ }^{+}=$ammonium, $\mathrm{TS}=$ total solids, $\mathrm{VS}=$ volatile solids. Tillage*Manure Timing treatments are: $\mathrm{CT}-\mathrm{C}=$ chisel control, $\mathrm{CT}-\mathrm{D}$ $=$ chisel with December manure, $\mathrm{CT}-\mathrm{J}=$ chisel with January manure, NT $-\mathrm{C}=$ no-tillage control, NT $-\mathrm{D}=$ notillage with December manure, NT $-\mathrm{J}=$ no-tillage with January manure. 

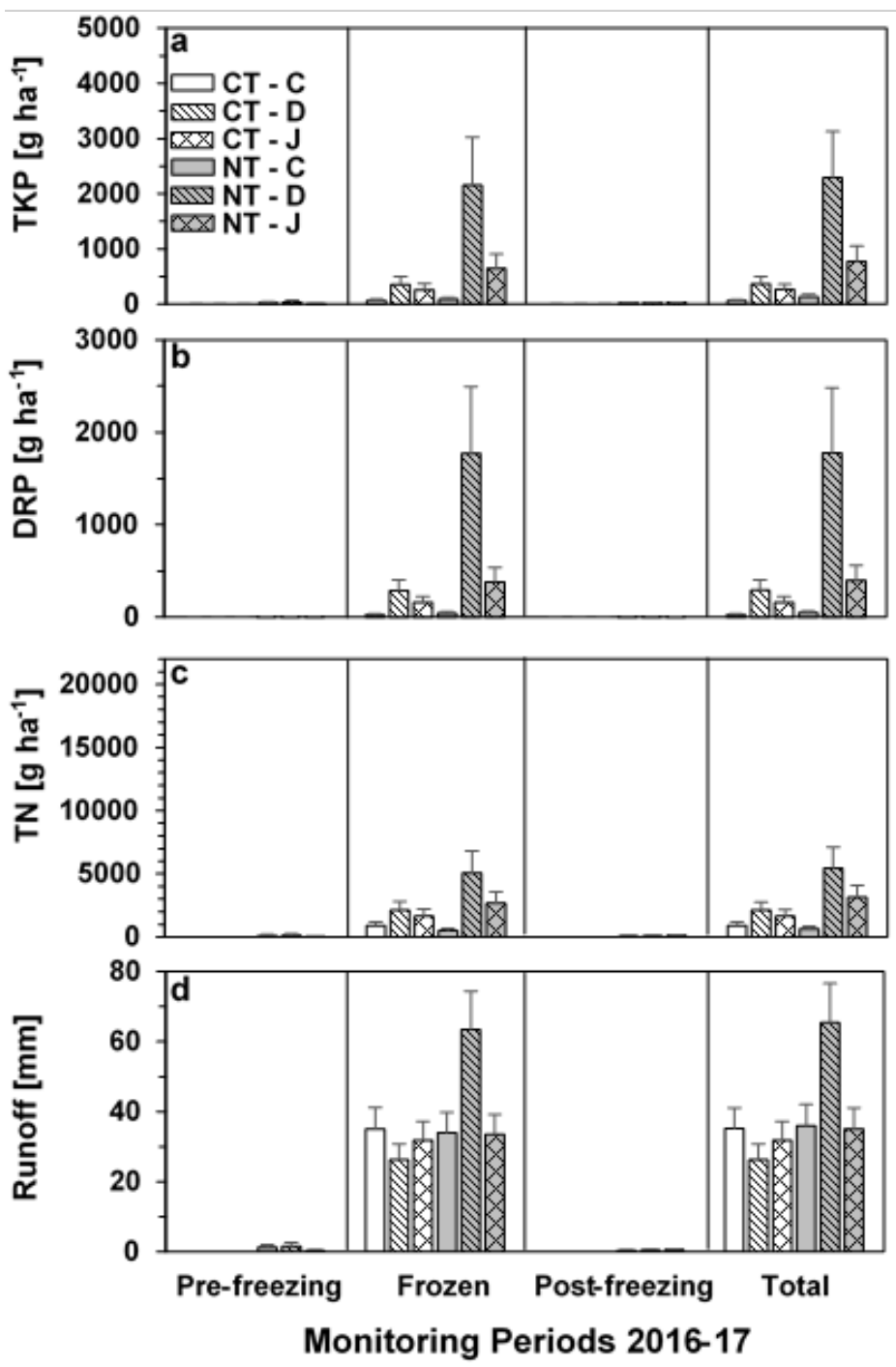

Figure 3. Treatment means ( \pm standard error) of a) Total Kjeldahl phosphorus (TKP), b) dissolved reactive phosphorus (DRP), c) total nitrogen (TN), and d) runoff by tillage $\mathrm{x}$ manure timing treatments during the 2016-17 monitoring season. Nutrients and runoff are shown within the pre-freezing, frozen-ground, and post-freezing periods, as well as the cumulative of the three periods (Total). [CT = fall tillage with a chisel plow, NT = no-tillage, Control $=$ no manure, Dec $=$ December manure timing, Jan $=$ January manure timing $]$.

Year-to-year weather introduced variability in the effectiveness of depressional storage, but surface roughness from tillage on the contour reduced overall runoff during both years. Tillage may be important during the freezing season when the risk of runoff is high in corn silage fields. These systems are particularly vulnerable because the bare soils - without residue or cover crops are less able to slow the velocity of runoff (Starkloff et al., 2017) without surface roughness (Ramos et al., 2016). The surface hydraulic conductivity may also be lower in NT compared to 
freshly tilled soils that have a lower bulk density (Lampurlanés and Cantero-Martínez, 2006; Ranaivoson et al., 2005). This difference may reduce the infiltration potential of NT during fieldsaturated conditions that are common from fall rain and spring melt in pre- and post-freezing seasons, respectively. The importance of ponding meltwater and rainfall may be emphasized for frozen soils, which have a reduced infiltration potential from pore ice (Iwata et al., 2011; Starkloff et al., 2017) and explain the lower runoff losses from Young and Mutchler's (1976) plowed fields.

\section{Nutrient Loads}

Differences in nutrient loads in runoff $(\mathrm{g} / \mathrm{ha})$ between $\mathrm{CT}$ and NT soils were a function of runoff hydrology and presence and condition of manure when runoff occurred. In 2015-16, the December manure application occurred on soil that was field-saturated, but not frozen or snowcovered, and the January application was on top of snow overlying soil frozen from the surface to a $50 \mathrm{~cm}$ depth (Figure $1 \mathrm{a}-\mathrm{c}$, Table 1). During this winter season, greater nutrient losses from NT soils were driven by greater runoff: as the runoff volume increased, the concentration of runoff nutrients also increased, as detailed by Vadas et al. (this issue). Subsequently, loads of TKP, DRP, TN, $\mathrm{NH}_{4}+$, TS, and VS were 44-276 times greater on NT than CT, which were all statistically significant as a main effect (Table 3). Most nutrient loss occurred during the frozen-ground and post-freezing periods with NT and solely the frozen-ground period with CT (Figure 2).

During 2016-17, the December application was atop of snow overlying soil frozen from the surface to a $10 \mathrm{~cm}$ depth, and the January application was atop of snow overlying soil that was thawed at the surface and frozen at depths of $6-44 \mathrm{~cm}$ (Figure 1, Table 1). The nutrient (TKP, DRP, TN, $\mathrm{NH}_{4}{ }^{+}$) and sediment (TS, VS) loads were only $1.5-3.4$ times greater on NT than CT, in part because there was more runoff from $\mathrm{CT}$ soil this second winter than during the first winter, which led to greater concentrations, hence loads, of runoff nutrients. Only TKP was significantly 
greater with NT as a main effect (Table 4), indicating nutrient losses in winter runoff are a function of hydrology that tillage may not fully control. It may also indicate that the increase in infiltration from fall tillage is greatest in the first year of tillage. At the same time, TN and TKP losses in NT controls, as well as the background nutrient levels of NT soils, were lower by the second year. Reducing some surface nutrient enrichment in NT may have also decreased differences between tillages. A need exists for longer-term studies that evaluate the effect of tillage on infiltration and soil fertility effects during the freezing season.

Nutrient loads in runoff were also driven by the presence of manure and availability of nutrients for transport when the runoff occurred, which was based on the application timing within each tillage. In 2015-16, the greatest nutrient loads occurred during the frozen-ground period, when most runoff was produced and nutrients from the January manure application were lost (Figure 2). Cumulative loads of the dissolved nutrients were significantly greater for NT - J compared to NT - C or NT - D (Table 3). There were no significant differences between NT - C and NT - D, though most nutrients were elevated numerically following both manure application timings. Volatile $\mathrm{S}$ losses in runoff, indicative of manure, were elevated from both manure timings compared to the unmanured control (Table 3). Greater losses from the January manure application timing over the December timing may be partly due to greater nutrients applied in January (Table 1), but are largely driven by the field conditions during manure application. 1.2 and 1.3 times as much TN and TP, respectively, were applied in January 2016 than in December 2015, but NT soils with the January application lost two times as much TN and TKP compared to NT soils with the December application (Table 3). This was due to manure application to unfrozen, snow-free soil in December 2015 and onto snow-covered soil with extensive frost development in January 2016. The liquid in the December-applied manure had a greater chance to infiltrate into the soil and be 
removed from risk of runoff loss compared to that in January because of the greater infiltration potential and hydraulic conductivity of unfrozen soils (Azmatch et al., 2012), which likely caused the lower runoff ratios. Some January-applied manure also stayed suspended in the snowpack, which further increased the chance of loss in runoff by accelerating snowmelt (Stock et at., 2019) and the availability of nutrients for surface transport. For event-by-event dynamics related to surface transport, see Vadas et al. (this issue). Overall, the restrictions on manure liquid infiltration by the presence and extent of frozen soils, manure application onto snow, contributed to the greater nutrient loads from the January manure application in 2015-16.

There were also significant differences between manure application timings within CT that followed trends from NT during 2015-16, though little runoff occurred from any of the CT treatments. All nutrient and sediment loads were significantly lower in CT $-\mathrm{C}$ and $\mathrm{CT}-\mathrm{D}$ than $\mathrm{CT}-\mathrm{J}$, and CT $-\mathrm{C}$ and $\mathrm{CT}-\mathrm{D}$ were not significantly different (Table 3). Nutrients had greater and sediment loads had lower numerical values in CT manure timings because the low runoff volumes likely had slow flow rates, thus an inability to carry significant sediment. Moreover, the only runoff event for CT was during the frozen ground period, when soil frost limited sediment losses (Vadas et al., this issue). Overall, the January manure timing resulted in the greatest loads on both tillages, but nutrient losses were 20-40 times lower when the manure was applied to CT soils. Nutrient concentrations in manure runoff are generally greatest during the first runoff events post application (Komiskey et al., 2011; Vadas et al., this issue). Therefore, manure nutrient loads in runoff were also likely reduced because the sole CT runoff event did not occur until 18-20 February 2016, weeks after either manure application took place. This delayed runoff timing combined with about ten times less runoff volume in CT than NT during the event - resulted in nutrient concentrations that were significantly lower in CT than NT. CT effectively reduced runoff 
at key times and was especially important during the frozen-ground period when the potential for surface nutrient transport is greatest and can account for most annual runoff losses (Good et al., 2012). The surface depressional storage thereby provided more time for nutrients in liquid manure, along with rain and snowmelt, to infiltrate.

Manure timings within tillages also had a significant effect on nutrient loads during 2016-17, but patterns were nearly opposite from 2015-16. Within both NT and CT, December and January manure timings significantly increased nutrient and sediment loads compared to their unmanured controls, but the greatest loads occurred from the December timing (Table 4). Greater losses from the December manure application timing over the January timing may be partly due to greater nutrients applied in December (Table 1), but also the field conditions during and after manure application. 1.0 and 1.2 times more TN and TP, respectively, were applied in December 2016 than in January 2017, but soils with the December application up to two times more TN and TKP compared to those with the January application (regardless of tillage) (Table 4). Both manure applications this winter were atop of snow and frozen soils, which restricted manure liquid infiltration into soil. However, the presence of surface thaw during application in January 2017, as opposed to soil frozen from the surface downward in December 2016, likely allowed some manure liquid and nutrients to immediately infiltrate into the soil, reducing manure nutrient loss potential in subsequent runoff events. Moreover, December and January were wet months. Prior to the January manure application, the December manure interacted with $134 \mathrm{~mm}$ precipitation and four runoff events on frozen soil, creating additional opportunities for surface nutrient transport. During this time prior to the January application, the runoff ratios of CT peaked, leading to greater runoff nutrient concentrations and ultimately, nutrient loads. 
Overall, the elevated loads from December and January manure timings, but especially during January 2016 and December 2016, was a function of the environmental conditions following application. Frozen soils increased the likelihood of runoff by lowering thresholds of available water (precipitation or snowmelt) needed to induce runoff (Vadas et al., 2017) by reducing infiltration. According to a laboratory investigation, the process of infiltration into a frozen soil follows three steps: 1) delayed or no initial infiltration, 2) slow infiltration as the wetting front advances through the soil frost layer, and 3) more rapid infiltration as the wetting front reaches the unfrozen soil beneath the frozen soil layer (Watanabe et al., 2011). During 2015-16, the presence of unfrozen soil in December versus substantial soil frost and snow in January (frost thickness $=$ $50.1 \mathrm{~cm}, \mathrm{SWE}=24 \mathrm{~mm}$ ) resulted in significantly greater runoff and nutrient loss from the January application. During 2016-17, both manure timings encountered soil frost, which elevated runoff, nutrient, and sediment losses from manure. There was a thinner soil frost layer and less snow accumulation during the December 2016 application (frost thickness $=10 \mathrm{~cm}, \mathrm{SWE}=10 \mathrm{~mm}$ ) than that in January 2017 (frost thickness $=38 \mathrm{~cm}, \mathrm{SWE}=31 \mathrm{~mm}$ ). Losses were likely lower in January 2017 because the surface layer of soil was thawed, allowing some manure liquid to immediately infiltrate the soil, thereby reducing the runoff ratio. Moreover, the December manure interacted with more precipitation and runoff events on frozen soil, therefore had more opportunity for surface losses - higher runoff ratios - before the January manure was even applied. From field observation, as manure was applied, the liquids rapidly infiltrated snow, leaving coarser solids suspended on the snow surface. Some manure remained trapped throughout the snow profile after percolation, while the rest of the liquid accumulated in the snow at the soil surface. When surface thaw of soil frost was present (i.e. January 2017), some liquid infiltrated the soil. When the soil surface was frozen (i.e. January 2016 and December 2016), the manure liquid that accumulated in 
the snow at the soil surface became an icy layer. Based on these processes, initial infiltration was delayed or did not occur for manure applications on soils with a frozen surface layer (i.e. January 2016 and December 2016), which led to more nutrient losses during subsequent runoff events, particularly when greater precipitation fell on frozen soils.

\section{CONCLUSION}

Wintertime manure applications pose a significant challenge to on-farm nutrient retention because of the limited infiltration potential of frozen soils, presence of snow, and likelihood of runoff during snowmelt and rain-on-snow events. Corn silage systems lack residue, thus surface

roughness from tillage is important in reducing runoff and nutrient transport. In this study, fall tillage reduced nutrient and sediment loads by reducing runoff volume, but was less effectiveness in the season with greater precipitation. Although fall tillage reduced winter runoff relative to notillage, erosion may be greater during the growing season and these seasonal tradeoffs must be quantified for year-round management decisions. Liquid manure application to unfrozen soil significantly reduced losses and partially-thawed soil helped to a lesser degree. Application atop snow to runoff risk by increasing the availability of nutrients for transport and accelerating snowmelt. Overall, however, timing manure applications was a less predictable control because runoff hydrology was strongly driven by seasonal weather and that led to an inherently greater risk of nutrient losses during winter. Additional research that investigates long-term field conditions, different soil textures, and infiltration rates on variably-saturated frozen soils would help establish physical processes that drive nutrient transport in winter. Tillage, frozen soil, snow cover, and weather should be considered with manure application during the freezing season to reduce the risk of nutrient loss to the environment. 


\section{Acknowledgments}

This work was funded by the USDA National Institute of Food and Agriculture, Agriculture and Food Research Initiative (Project \#3958). Additional research assistantship support for M.N.S. was provided by the University of Wisconsin-Madison Champ B. Tanner Agricultural Physics Award and other funding was provided by the NCR SARE Graduate Student Grant (Project \#GNC14-197) and Decagon Devices GA Harris Fellowship (2014). This research was also supported by the Utah Agricultural Experiment Station, Utah State University. We thank Mike Bertram and staff at the Arlington Agricultural Research Station, Nick Bero, Joe Bevington, Andy Larson, Jim Richmond, and Peter Wakeman for their field and laboratory assistance.

\section{REFERENCES}

APHA. (1995). Standard Methods for the Examination of Water and Wastewater, 19th edition. American Public Health Association, Washington, D.C.

Azmatch, T.F., Sego, D.C., Arenson, L.U., and Biggar, K.W. (2012). Using soil freezing characteristic curve to estimate the hydraulic conductivity function of partially frozen soils. Cold Reg Sci Technol, 83-84, $103-109$. https://doi.org/10.1016/j.coldregions.2012.07.002

Bonilla, C.A., Kroll, D.G., Norman, J.M., Yoder, D.C., Molling, C.C., Miller, P.S., Panuska, J.C., Topel, J.B., Wakeman, P.L., and Karthikeyan, K.G. (2006). Instrumentation for measuring runoff, sediment, and chemical losses from agricultural fields. J. Environ. Qual., 35(1), 216-23. https://doi.org/10.2134/jeq2005.0130.

Converse, J.C., Bubenzer, G.D., and Paulson, W.H. (1976). Nutrient Losses in Surface Runoff from Winter Spread Manure. Trans. ASAE., 19, 517-519. https://doi.org/10.13031/2013.36061

Daniel, T.C., Sharpley, A.N., and Lemunyon, J.L. (1998). Agricultural Phosphorus and Eutrophication: A Symposium Overview. J. Environ. Qual., 27, 251-257.

Feng, S. and Hu, Qi. (2007). Changes in winter snowfall/precipitation ratio in the contiguous United States. J. Geophys. Res., 112, D15109. https://doi.org/10.1029/2007JD008397.

Good, L.W., Vadas, P.A., Panuska, J.C., Bonilla, C.A., and Jokela, W.E. (2012). Testing the Wisconsin Phosphorus Index with Year-Round, Field-Scale Runoff Monitoring. J. Environ. Qual., 41, 1730-1740. https://doi.org/10.2134/jeq2012.0001

Hansen, N.N., Gupta, S.C., and Moncrief, J.F. (2000). Snowmelt runoff, sediment, and phosphorus losses under three different tillage systems. Soil Till Res., 57, 97-100. https://doi.org/10.1016/S0167-1987(00)00152-5.

Hensler, R.F., Olson, R.J., Witzel, S.A., Attoe, O.J., Paulson, W.H., and Johannes, R.F. (1970). Effect of method of manure handling on crop yields, nutrient recovery, and runoff losses. T. ASAE., 13(6), 726-731.

https://doi.org/10.13031/2013.38706

Iwata, Y., Hayashi, M., Suzuki, S., Hirota, T., and Hasegawa, S. (2010), Effects of snow cover on soil freezing, water movement, and snowmelt infiltration: A paired plot experiment. Water Resour. Res., 46, W09504. https://doi.org/10.1029/2009WR008070

Klausner, S.D., Zwerman, P.J., and Ellis, D.F. (1976). Nitrogen and Phosphorus Losses from Winter Disposal of Dairy Manure. J. Environ. Qual., 5, 47-49. https://doi.org/10.2134/jeq1976.00472425000500010010x 
Kleinman, P.J., and Sharpley, A.N. (2003). Effect of broadcast manure on runoff phosphorus over successive rainfall events. J. Environ. Qual., 32, 1072-1081. https://doi.org/10.2134/jeq2003.1072

Kongoli, C.E., and Bland, W.L. (2002). Influence of manure application on surface energy and snow cover: Field experiments. J. Environ. Qual., 31, 1166-1173. https://doi.org/10.2134/jeq2002.1174

Komiskey, M.J., Stuntebeck, T.D., Frame, D.R., and Madison, F.W. (2011). Nutrients and sediment in frozenground runoff from no-till fields receiving liquid-dairy and solid-beef manures. J. Soil Water Conserv., 66(5), 303-312. https://doi.org/10.2489/jswc.66.5.303

Lampurlanés, J. and Cantero-Martínez, C. (2006). Hydraulic conductivity, residue cover and soil surface roughness under different tillage systems in semi-arid conditions. Soil Till Res., 85(1-2), 13-26. https://doi.org/10.1016/j.still.2004.11.006

Lewis, T.W. and Makarewicz, J.C. (2009). Winter application of manure on an agricultural watershed and its impacts on downstream nutrient fluxes. J. Great Lake Res., 35(sp1), 43-49. https://doi.org/10.1016/j.jglr.2008.08.003

Liu, J., Kleinman P.J.A., Aronsson H., Bechmann M., Beegle D.B., Bryant R.B., Flaten D., Liu H.B., McDowell R.W., Robinson T.P., Sharpley A.N., Veith T.L. (2018). A global review of regulations and guidelines related to winter manure application. Ambio 47, 657-670. https://doi.org/10.1007/s13280-018-1012-4

Liu, J., Veith, T. L., Collick, A. S., Kleinman, P. J. A., Beegle, D. B., and Bryant, R. B. (2017). Seasonal Manure Application Timing and Storage Effects on Field- and Watershed-Level Phosphorus Losses. J. Environ. Qual., 46, 1403-1412. https://doi.org/10.2134/jeq2017.04.0150

Liu, K., Elliott, J. A., Lobb, D. A., Flaten, D. N., and Yarotski. J. (2014). Conversion of conservation tillage to rotational tillage to reduce phosphorus losses during snowmelt runoff in the Canadian Prairies. J. Environ. Qual., 43, 1679-1689. https://doi:10.2134/jeq2013.09.0365

MacKay, J.R. (1973). A frost tube for the determination of freezing in the active layer above permafrost. Can. Geotech. J., 10, 392-396. https://doi.org/10.1139/t73-033

National Oceanic and Atmospheric Administration (NOAA). (2017). NOAA National Centers for Environmental Information Data Tools: 1981-2010 Normals. Retrieved from: https://www.ncdc.noaa.gov/data-access/landbased-station-data/land-based-datasets/climate-normals/1981-2010-normals-data

Owens, L.B., Bonta, J.V., Shipitalo, M.J., and Rogers, S. (2011). Effects of winter manure application in Ohio on the quality of surface runoff. J. Environ. Qual., 40, 153-165. https://doi.org/10.2134/jeq2010.0216

Peters, J., Combs, S.M., Hoskins, B., Jarman, J., Kovar, J.L., Watson, M.E., Wolf, A.M., and Wolf, N. (2003). Recommended Methods of Manure Analysis. Cooperative Extension Publishing University of WisconsinExtension Publication A3769. http://learningstore.uwex.edu/assets/pdfs/A3769.pdf

Phillips, P.A., Culley, J.L.B., Hore, F.R., Patni, N.K. (1981). Pollution potential and corn yields from selected rates and timing of liquid manure applications. T. ASAE, 24, 139-144. https://doi.org/10.13031/2013.34213

Ramos, J.C., Bertol, I. Barbosa, F.T., Bertól, C., Mafra, A.L., Miquelluti, D.J., and Júnior, J.M. (2016). Water erosion in surface soil conditions: runoff velocity, concentration and D50 index of sediments in runoff. Sci Agric. (Piracicaba, Braz.), 73 (3), 286-293. http://dx.doi.org/10.1590/0103-9016-2015-0110. 
Ranaivoson, A.Z.H., Moncrief, J.F., Hansen, N.C., and Gupta, S.C. (2005). Effect of fall tillage following soybeans on organic matter losses in snowmelt. Soil Till. Res., 81 (2), 205-216. https://doi.org/10.1016/j.still.2004.09.008.

Rickard, W., and Brown, J. (1972). The performance of a frost-tube for the determination of soil freezing and thawing depths. Soil Sci., 113(2), 149-154. https://doi.org/10.1097/00010694-197202000-00011

SEAL Analytical Inc. (2015). Discrete Analyzer EPA Methods. Retrieved from: sealanalytical.com.tempdomain.com/Methods/DiscreteMethods/DiscreteAnalyzerEPAMetho ds/tabid/76/language/en-US/Default.aspx. Accessed 22 Nov. 2017).

Srinivasan, M.S., Bryant, R.B., Callahan, M.P., and Weld, J.L. (2006). Manure management and nutrient loss under winter conditions: A literature review. J. Soil Water Conserv., 61, 200-209. https://doi.org/10.2489/jswc.68.3.185

Starkloff, T., Hessel, R., Stolte, J., Ritsema, C. (2017). Catchment hydrology during winter and spring and the link to soil erosion: a case study in Norway. Hydrology, 4(1), 1-17. https://doi.org/10.3390/hydrology4010015

Steenhuis, T.S., Bubenzer, G.D., Converse, J.C., Walter, M.F. (1981). Winter-spread manure Nitrogen loss. T. ASAE, 24 (2), 0436-0441. https://doi.org/10.13031/2013.34270

Stock, M.N., Arriaga, F.J., Vadas, P.A., and Karthikeyan, K.G.. 2019. Manure application timing drives energy absorption for snowmelt on an agricultural soil. J. Hydrol. 549: 51-60. doi:10.1016/j.jhydrol.2018.11.028

Stroup, W.W. (2013). Generalized Linear Mixed Models: Modern Concepts, Methods, and Applications. Boca Raton, FL: CRC Press.

Stuntebeck, T.D., Komiskey, M.J., Peppler, M.C., Owens, D.W., and Frame, D.R. (2011). Precipitation-runoff relations and water quality characteristics at edge-of-field stations, Discovery Farms and Pioneer Farm, Wisconsin, 2003-8. SIR; 2011-5008: U.S.G.S. Scientific Investigations Report. Retrieved from: https://pubs.usgs.gov/sir/2011/5008/

Tiessen, K.H.D., Elliott, J.A., Yarotski, J., Lobb, D.A., Flaten, D.N., and Glozier, N.E. (2010). Conventional and Conservation Tillage: Influence on Seasonal Runoff, Sediment, and Nutrient Losses in the Canadian Prairies. J. Environ. Qual., 39, 964-980. https://doi.org/10.2134/jeq2009.0219

University of Wisconsin. (2010). UW Extension Ag Weather: NWS Co-Op Observer Reports. Retrieved from: http://agwx.soils.wisc.edu/uwex_agwx/weather/hyd. Accessed: 13 October 2017.

U.S. Army Corps of Engineers. (2015). Measuring plains snow water equivalent and depth: Missouri Basin Water Management Division and Omaha District Method. Northwestern Division, Missouri River Basin Water Management Division. Retrieved from: http://www.nwd-mr.usace.army.mil/rcc/. Accessed 23 February 2018.

USDA-NASS. (2010). Overview of the United States Dairy Industry. Agricultural Statistics Board. Retrieved from: http://usda.mannlib.cornell.edu/usda/current/USDairyIndus/USDairyIndus-09-22-2010.pdf. Accessed: 13 October 2017.

USDA NRCS (Natural Resources Conservation Service). (2015). Conservation Practice Standard 590. Wisconsin Field Office Technical Guide. Retrieved from: https://efotg.sc.egov.usda.gov/references/public/WI/590.pdf. Accessed: 13 October 2017. 
USEPA. (2015). US EPA Watershed Assessment, Tracking, and Environmental Results. Retrieved from: http://ofmpub.epa.gov/waters10/attains_nation_cy.control. Accessed: 13 October 2017.

Vadas, P. A., Good, L.W., Jokela, W.E., Karthikeyan, K.G., Arriaga, F.J., and Stock, M.N. (2017). Quantifying the impact of seasonal and short-term manure application decisions on phosphorus loss in surface runoff. J. Environ. Qual. 46,1395-1402. https://doi.org/10.2134/jeq2016.06.0220.

Vadas, P.A., Stock, M.N., Feyereisen, G.W., Arriaga, F.J., Good, L.W., and Karthikeyan, K.G. (2018). Temperature and manure placement in a snowpack affect nutrient release from dairy manure during snowmelt. J. Environ. Qual. 47, 848-855. https://doi.org/10.2134/jeq2017.12.0464

Vadas, P.A., Harmel, R.D., and Kleinman, P.J.A. (2007). Transformations of soil and manure phosphorus after surface application of manure to field plots. Nutr. Cycl. Agroeco., 77, 83-99. https://doi.org/10.1007/s10705006-9047-5

Vadas, P.A. and Powell, J.M. (2013). Monitoring nutrient loss in runoff from dairy cattle lots. Agr. Ecosyst. Environ., 181, 127-133. https://doi.org/10.1016/j.agee.2013.09.025.

Watanabe, K., Kito, T., Dun, S., Wu, J.Q., Greer, R.C., and Flury, M. (2013). Water infiltration into a frozen soil with simultaneous melting of the frozen layer. Vadose Zone J., 12 (1). https://doi/org/10.2136/vzj2011.0188

Young, R.A. and Holt, R.F. (1977). Winter-applied manure: Effects on annual runoff, erosion, and nutrient movement. J. Soil Water Conserv., 32, 219-222.

Young, R.A., and Mutchler, C.K. (1976). Pollution potential of manure spread on frozen ground. J. Environ. Qual., 5, 174-179. https://doi.org/10.2134/jeq1976.00472425000500020013x

Zhang, G.S., Chang, K.Y., Oates, A., Heenan, D.P., and Huang, G.B. (2007). Relationship between soil structure and runoff/soil loss after 24 years of conservation tillage. Soil Till Res., 92(1-2), 122-128. https://doi.org/10.1016/j.still.2006.01.006. 


\section{FIGURES AND TABLES}

Figure 1. Average hourly air temperature and total daily precipitation as rainfall or the liquid equivalent of snowfall during a) 2015-16 and d) 2016-17; the snow-water equivalent (SWE) of snowpack during b) 2015-16 and e) 201617; and the average frost depth during c) 2015-16 and f) 2016-17. Runoff event dates are designated in a, b, d, and e with pink, vertical lines; and manure application dates are denoted with an asterisks in $\mathrm{b}$ and $\mathrm{e}$.

Figure 2. Treatment means ( \pm standard error) of a) Total Kjeldahl phosphorus (TKP), b) dissolved reactive phosphorus (DRP), c) total nitrogen (TN), and d) runoff by tillage x manure timing treatments during the 2015-16 monitoring season. Nutrients and runoff are shown within the pre-freezing, frozen-ground, and post-freezing periods, as well as the cumulative of the three periods (Total). [CT = fall tillage with a chisel plow, NT = no-tillage, Control $=$ no manure, Dec $=$ December manure timing, Jan $=$ January manure timing $]$.

Figure 3. Treatment means ( \pm standard error) of a) Total Kjeldahl phosphorus (TKP), b) dissolved reactive phosphorus (DRP), c) total nitrogen (TN), and d) runoff by tillage x manure timing treatments during the 2016-17 monitoring season. Nutrients and runoff are shown within the pre-freezing, frozen-ground, and post-freezing periods, as well as the cumulative of the three periods (Total). [CT = fall tillage with a chisel plow, NT = no-tillage, Control $=$ no manure, Dec $=$ December manure timing, Jan $=$ January manure timing $]$.

Table 1. The dates and nutrient additions for each manure application with the corresponding field conditions during the application dates.

\begin{tabular}{|c|c|c|c|c|c|c|c|}
\hline \multirow[b]{2}{*}{$\begin{array}{l}\text { Application } \\
\text { Date }\end{array}$} & \multicolumn{5}{|c|}{ Manure Analysis ${ }^{\dagger}$} & \multicolumn{2}{|c|}{ Field Conditions ${ }^{\dagger}$} \\
\hline & TN & $\begin{array}{l}\text { TP } \\
\mathrm{kg} \mathrm{ha}^{-}\end{array}$ & TK & & $\begin{array}{l}\mathbf{V S} \\
]---\end{array}$ & $\begin{array}{c}\text { Frost Depth } \\
{[\mathrm{cm}]}\end{array}$ & $\begin{array}{l}\text { SWE } \\
{[\mathrm{mm}]}\end{array}$ \\
\hline 10 Dec. 2015 & 65.9 & 8.7 & 68.2 & 2.0 & 1.3 & 0.0 & 0 \\
\hline 26 Jan. 2016 & 80.6 & 11.3 & 56.3 & 2.9 & 2.0 & $0.0-50.1$ & 24 \\
\hline 09 Dec. 2016 & 102.9 & 17.8 & 53.1 & 5.8 & 4.4 & $0.0-10.4$ & 10 \\
\hline 27 Jan. 2017 & 99.2 & 14.4 & 57.5 & 5.5 & 4.1 & $6.2-43.9$ & 31 \\
\hline
\end{tabular}

$\mathrm{TTN}=$ total nitrogen, $\mathrm{TP}=$ total phosphorus, $\mathrm{TK}=$ total potassium, $\mathrm{TS}=$ total solids, and VS = volatile solids from manure on each of the four application dates. $\mathrm{SWE}=$ snow-water equivalent.

Table 2. Pre-freezing, frozen-ground, and post-freezing periods during the 2015-16 and 2016-17 monitoring seasons according to soil frost dates. Precipitation for each period is given as rainfall and snowfall, with snowfall expressed in liquid equivalents (SWE). Corresponding runoff events are given for soils with no-tillage (NT) and fall tillage with a chisel plow (CT).

\begin{tabular}{|c|c|c|c|c|c|c|c|}
\hline \multirow[t]{2}{*}{ Year } & \multirow[t]{2}{*}{ Period } & & \multirow[t]{2}{*}{$\begin{array}{l}\text { \# Days } \\
\text { Frozen }\end{array}$} & \multicolumn{2}{|c|}{$\begin{array}{c}\text { Precipitation } \\
--[\mathrm{mm}]--\end{array}$} & \multicolumn{2}{|c|}{$\begin{array}{c}\text { \# Runoff } \\
\text { Events }\end{array}$} \\
\hline & & & & Rain & SWE & NT & CT \\
\hline \multirow{3}{*}{$\begin{array}{l}2015- \\
2016\end{array}$} & Pre-freezing & $24 \mathrm{Nov}-29 \mathrm{Dec}$ & \multirow[t]{3}{*}{74} & 132 & 7 & 2 & 0 \\
\hline & Frozen-ground & 30 Dec-11 Mar & & 24 & 24 & 5 & 1 \\
\hline & Post-freezing & $12 \mathrm{Mar}-30 \mathrm{Apr}$ & & 105 & 17 & 2 & 0 \\
\hline \multirow{3}{*}{$\begin{array}{l}2016- \\
2017\end{array}$} & Pre-freezing & $24 \mathrm{Nov}-06 \mathrm{Dec}$ & \multirow[t]{3}{*}{$94+$} & 75 & 12 & 1 & 0 \\
\hline & Frozen-ground & $07 \mathrm{Dec}-22 \mathrm{Feb}, 03$ - $20 \mathrm{Mar}$ & & 102 & 87 & 8 & 6 \\
\hline & Post-freezing & $23 \mathrm{Feb}-02 \mathrm{Mar}, 21 \mathrm{Mar}-30 \mathrm{Apr}$ & & 163 & 7 & 1 & 0 \\
\hline
\end{tabular}

$\dagger$ The frozen-ground and post-freezing periods of 2016-17 are discontinuous because the soil thawed between 23 Feb. and 02 Mar. 2017, and refroze by 03 Mar. 2017. 
Table 3. Treatment means and $p$-values for comparisons of tillage, manure timing, and tillage $\mathrm{x}$ manure timing effects on total loads in the 2015-16 monitoring season $\dagger$.

\begin{tabular}{|c|c|c|c|c|c|c|c|c|c|}
\hline \multirow{2}{*}{\multicolumn{3}{|c|}{ Effect }} & \multirow{2}{*}{$\begin{array}{l}\text { Runoff } \\
{[\mathrm{mm}]}\end{array}$} & \multirow[t]{2}{*}{ TKP } & DRP & TN & \multirow{2}{*}{$\mathrm{NH}_{4}^{+}$} & \multirow{2}{*}{\multicolumn{2}{|c|}{$\begin{array}{l}\text { TS VS } \\
--\left[\mathrm{kg} \mathrm{ha}^{-1}\right]--\end{array}$}} \\
\hline & & & & & ------- [q & $\left.\mathbf{h a}^{-1}\right]-$ & & & \\
\hline \multirow{3}{*}{ 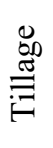 } & Tillage with chisel (CT) & & 1.3 & 7.2 & 3.8 & 56.7 & 11.9 & 2.7 & 1.1 \\
\hline & No-Tillage (NT) & & 38.8 & 1432 & 209 & 5943 & 525 & 746 & 126 \\
\hline & CT vs. NT & $p=$ & 0.01 & $<0.01$ & $<0.01$ & 0.01 & 0.01 & $<0.01$ & 0.01 \\
\hline \multirow{6}{*}{ 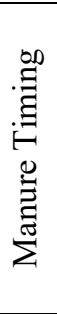 } & Control (C) & & 5.5 & 55.2 & 8.8 & 336 & 38.3 & 33.8 & 9.0 \\
\hline & December (D) & & 4.2 & 42.5 & 9.3 & 291 & 27.2 & 26.2 & 6.5 \\
\hline & January $(J)$ & & 15.7 & 443 & 269 & 2005 & 476 & 99.8 & 29.5 \\
\hline & C vs. D & $p=$ & 1.00 & 1.00 & 1.00 & 1.00 & 1.00 & 1.00 & 1.00 \\
\hline & C vs. J & $p=$ & 0.11 & 0.01 & $<0.01$ & 0.02 & 0.01 & 0.11 & 0.12 \\
\hline & D vs. J & $p=$ & 0.03 & $<0.01$ & $<0.01$ & 0.01 & $<0.01$ & 0.03 & 0.03 \\
\hline \multirow{12}{*}{ 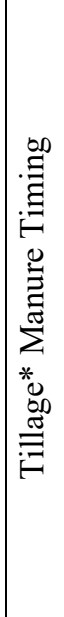 } & $\mathrm{CT}-\mathrm{C}$ & & 0.9 & 3.5 & 1.1 & 33 & 5.3 & 1.6 & 0.9 \\
\hline & $\mathrm{CT}-\mathrm{D}$ & & 0.4 & 1.5 & 0.8 & 17 & 3.1 & 0.9 & 0.4 \\
\hline & $\mathrm{CT}-\mathrm{J}$ & & 5.7 & 70 & 61 & 326 & 104 & 13 & 5.0 \\
\hline & $\mathrm{NT}-\mathrm{C}$ & & 33.0 & 881 & 68 & 3379 & 275 & 720 & 94 \\
\hline & NT $-\mathrm{D}$ & & 40.6 & 1197 & 113 & 5045 & 241 & 769 & 122 \\
\hline & NT $-J$ & & 43.5 & 2784 & 1192 & 12313 & 2191 & 750 & 174 \\
\hline & $\mathrm{CT}-\mathrm{C}$ vs. $\mathrm{CT}-\mathrm{D}$ & $p=$ & 0.60 & 0.34 & 1.00 & 0.66 & 1.00 & 0.93 & 0.56 \\
\hline & $\mathrm{CT}-\mathrm{C}$ vs. $\mathrm{CT}-\mathrm{J}$ & $p=$ & 0.06 & 0.01 & $<0.01$ & 0.03 & 0.01 & 0.04 & 0.10 \\
\hline & $\mathrm{CT}-\mathrm{D}$ vs. $\mathrm{CT}-\mathrm{J}$ & $p=$ & 0.05 & 0.01 & 0.02 & 0.03 & 0.05 & 0.01 & 0.03 \\
\hline & $\mathrm{NT}-\mathrm{C}$ vs. NT $-\mathrm{D}$ & $p=$ & 1.00 & 1.00 & 0.94 & 1.00 & 1.00 & 1.00 & 1.00 \\
\hline & $\mathrm{NT}-\mathrm{C}$ vs. NT $-\mathrm{J}$ & $p=$ & 1.00 & 0.15 & 0.01 & 0.16 & 0.05 & 1.00 & 1.00 \\
\hline & NT $-\mathrm{D}$ vs. NT $-\mathrm{J}$ & $p=$ & 1.00 & 0.21 & 0.01 & 0.26 & 0.02 & 1.00 & 1.00 \\
\hline
\end{tabular}

†TKP $=$ total Kjeldahl phosphorus, $\mathrm{DRP}=$ dissolved reactive phosphorus, $\mathrm{TN}=$ total nitrogen, $\mathrm{NH}_{4}{ }^{+}=$ammonium, $\mathrm{TS}=$ total solids, $\mathrm{VS}=$ volatile solids. Tillage*Manure Timing treatments are: $\mathrm{CT}-\mathrm{C}=$ chisel control, $\mathrm{CT}-\mathrm{D}$ $=$ chisel with December manure, $\mathrm{CT}-\mathrm{J}=$ chisel with January manure, $\mathrm{NT}-\mathrm{C}=$ no-tillage control, $\mathrm{NT}-\mathrm{D}=$ notillage with December manure, NT $-\mathrm{J}=$ no-tillage with January manure. 
Table 4. Treatment means and p-values for comparisons of tillage, manure timing, and tillage*manure timing effects on total loads in the 2016-17 monitoring season†े.

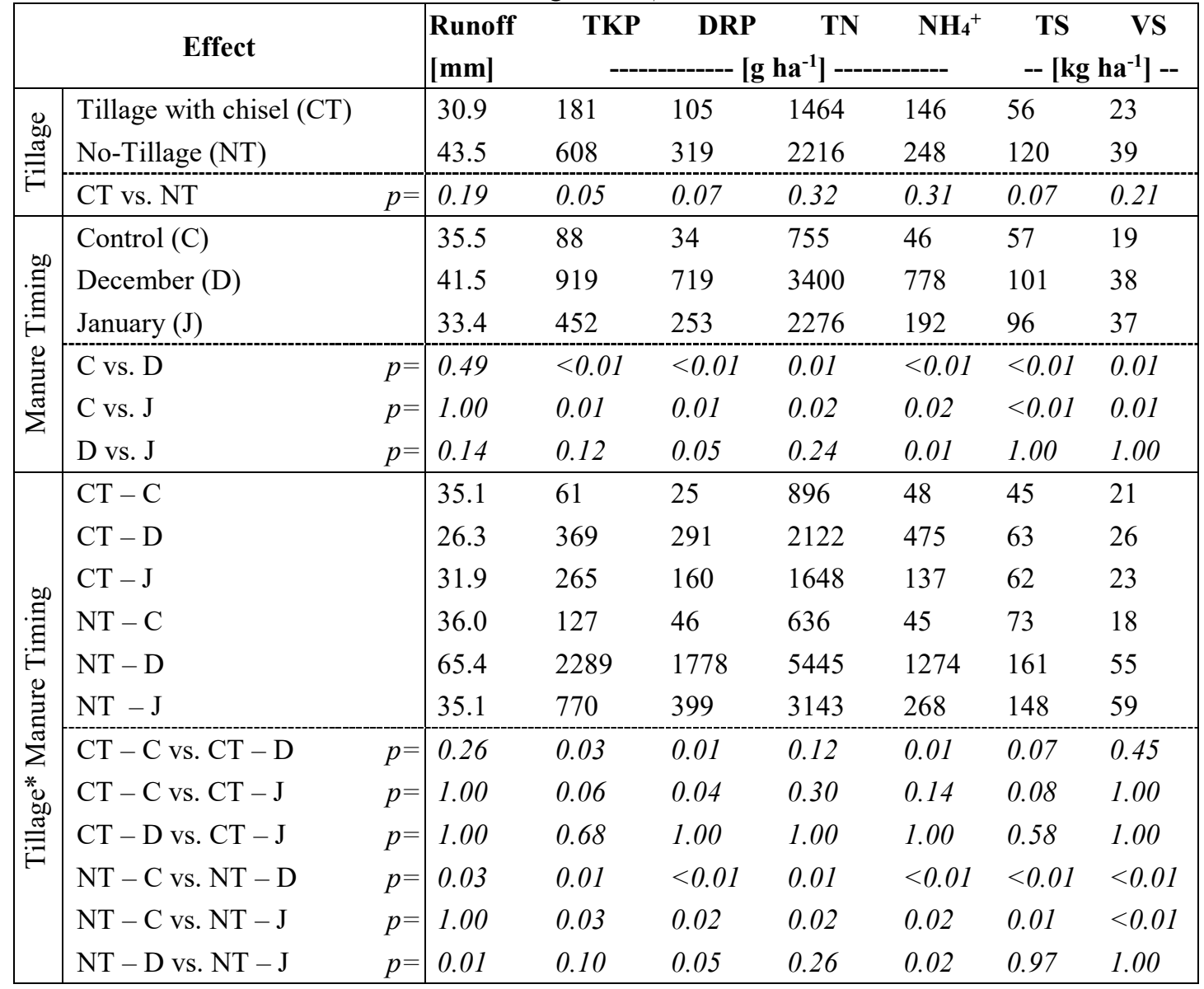

†TKP $=$ total Kjeldahl phosphorus, $\mathrm{DRP}=$ dissolved reactive phosphorus, $\mathrm{TN}=$ total nitrogen, $\mathrm{NH}_{4}{ }^{+}=$ammonium, $\mathrm{TS}=$ total solids, $\mathrm{VS}=$ volatile solids. Tillage*Manure Timing treatments are: $\mathrm{CT}-\mathrm{C}=$ chisel control, $\mathrm{CT}-\mathrm{D}$ $=$ chisel with December manure, $\mathrm{CT}-\mathrm{J}=$ chisel with January manure, NT $-\mathrm{C}=$ no-tillage control, NT $-\mathrm{D}=$ notillage with December manure, NT $-\mathrm{J}=$ no-tillage with January manure. 


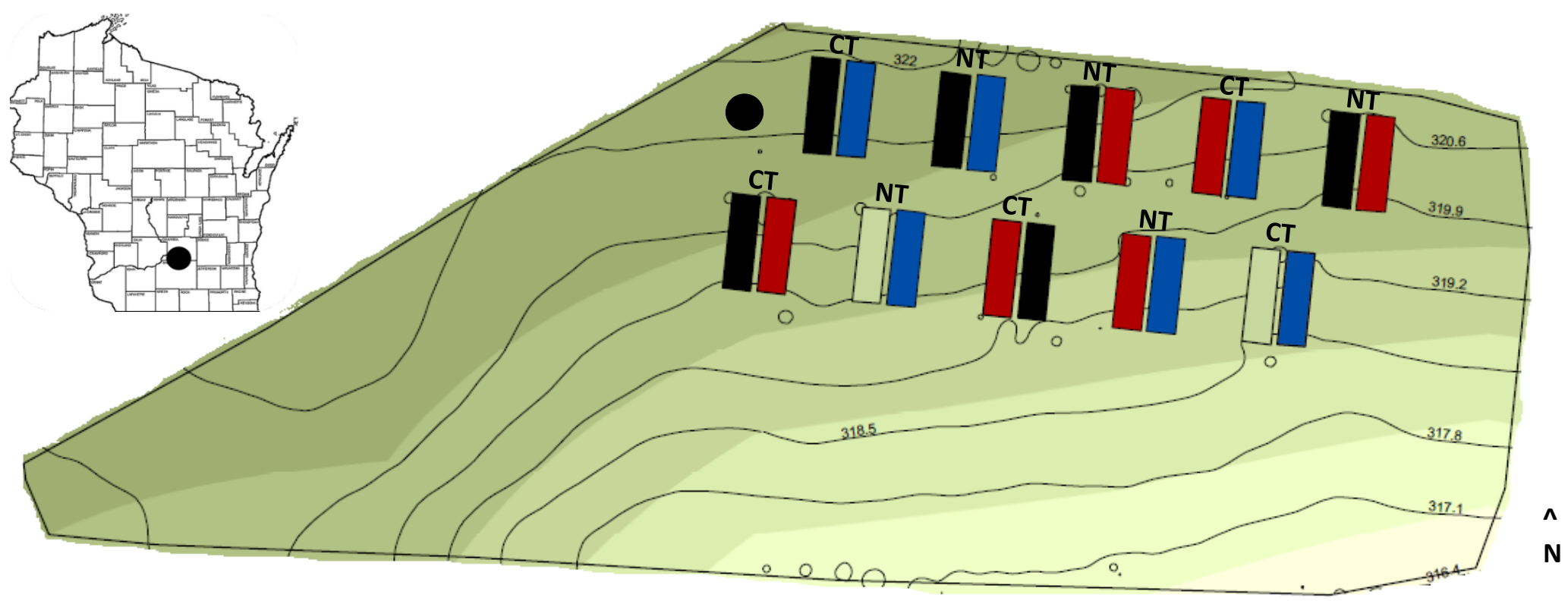

Supplemental Figure. Diagram of the experimental design at the field site located in south-central Wisconsin, at the University of Wisconsin Agricultural Research Station - Arlington. The plots were arranged in pairs according to tillage. Five of the pairs were assigned to no-tillage (NT) and five pairs were assigned to tillage (CT), arranged in a completely randomized design. Two of the three manure application treatments were assigned within each pair, completely at random, but balanced between the NT and CT treatments. Manure application treatments are color-coded as the unmanured control in blue, December application in red, January application in black, and blank plots in green. The location of the on-site weather station is shown by the black circle. 
Supplemental Table. Air temperature expressed as monthly averages (Ave), minimums (Min), and maximums (Max); total monthly precipitation; and soil frost dates during 2015-2016 and 2016-2017, compared to historic weather trends.

\begin{tabular}{|c|c|c|c|c|c|c|c|c|}
\hline \multirow[t]{2}{*}{ Year } & \multirow[t]{2}{*}{ Month } & \multicolumn{3}{|c|}{$\underline{\text { Air Temperature }\left[{ }^{\circ} \mathrm{Cl}\right.}$} & \multirow[t]{2}{*}{ Precipitation [mm] } & \multicolumn{3}{|c|}{ Soil frost dates } \\
\hline & & Ave & Min & Max & & Freeze & Thaw & Days frozen \\
\hline \multirow[t]{6}{*}{$2015-16$} & November & 5.4 & -12.8 & 22.0 & 129 & $30 \mathrm{Dec}$ & $12 \mathrm{Mar}$ & 74 \\
\hline & December & 1.0 & -12.0 & 14.7 & 82 & & & \\
\hline & January & -7.1 & -24.0 & 4.1 & 25 & & & \\
\hline & February & -3.5 & -21.1 & 13.3 & 13 & & & \\
\hline & March & 4.1 & -15.2 & 20.0 & 103 & & & \\
\hline & April & 7.3 & -9.4 & 26.2 & 27 & & & \\
\hline \multirow[t]{6}{*}{$2016-17$} & November & 6.4 & -7.3 & 21.9 & 45 & $7 \mathrm{Dec}$ & $23 \mathrm{Feb}$ & 94 \\
\hline & December & -5.8 & -25.2 & 5.1 & 65 & $3 \mathrm{Mar}$ & $21 \mathrm{Mar}$ & \\
\hline & January & -5.3 & -21.6 & 5.8 & 83 & & & \\
\hline & February & -0.3 & -16.2 & 19.8 & 64 & & & \\
\hline & March & 0.4 & -16.3 & 16.3 & 52 & & & \\
\hline & April & 9.8 & -0.5 & 23.6 & 109 & & & \\
\hline Historic & November & 0.9 & -4.6 & 6.4 & 61 & 19 Nov (2) & $22 \operatorname{Mar}(4)$ & $118(6)$ \\
\hline \multirow[t]{5}{*}{ Weather ${ }^{\mathrm{a}}$} & December & -6.4 & -11.7 & -1.3 & 37 & & & \\
\hline & January & -9.0 & -14.6 & -3.4 & 29 & & & \\
\hline & February & -6.5 & -12.1 & -0.9 & 33 & & & \\
\hline & March & -0.3 & -6.4 & 5.7 & 48 & & & \\
\hline & April & 7.1 & 0.1 & 14.0 & 89 & & & \\
\hline
\end{tabular}

Note. Total monthly precipitation (rainfall + snowfall) expressed in liquid equivalents.

${ }^{a}$ Monthly air temperature and precipitation based on 1981-2010 normals, recorded $16 \mathrm{~km}$ south of the field site at the Dane County Regional Airport in Madison, WI (NOAA, 2017). Average soil frost dates ( \pm one standard deviation) based on 10-year averages (2005-2014), recorded $13 \mathrm{~km}$ west of the field site in Lodi, WI

(University of Wisconsin, 2010). 